\title{
Phosphorus Availability, Uptake and Dry Matter Yield of Indian Spinach (Basella alba L.) to Lime and Phosphorus Fertilization in an Acidic Soil
}

\author{
Ashoka Sarker, Md. Abul Kashem*, Khan Towhid Osman
}

Department of Soil Science, University of Chittagong, Chittagong, Bangladesh.

Email: ${ }^{\text {kashem00@yahoo.com }}$

Received December $5^{\text {th }}, 2013$; revised January $5^{\text {th }}, 2014$; accepted January $12^{\text {th }}, 2014$

Copyright (C 2014 Ashoka Sarker et al. This is an open access article distributed under the Creative Commons Attribution License, which permits unrestricted use, distribution, and reproduction in any medium, provided the original work is properly cited. In accordance of the Creative Commons Attribution License all Copyrights (C) 2014 are reserved for SCIRP and the owner of the intellectual property Ashoka Sarker et al. All Copyright (C) 2014 are guarded by law and by SCIRP as a guardian.

\section{ABSTRACT}

A pot experiment was carried out to investigate the yield of Indian spinach (Basella alba L.) and their uptake and availability of phosphorus from lime and phosphorus amended acidic soil. Four rates of lime (L) equivalent to 0 , 500,1000 and $2000 \mathrm{~kg} \mathrm{CaCO}_{3} \mathrm{ha}^{-1}$ and four rates of phosphorus $(\mathrm{P})$ equivalent to $0,50,100$, and $^{150} \mathrm{~kg} \cdot \mathrm{P} \cdot \mathrm{ha} \mathrm{of}^{-1}$ TSP were applied in combinations as treatments. Dry matter yield, $\mathbf{P}$ concentrations in shoot and root and $\mathbf{P}$ uptake by Indian spinach were determined after harvesting 10 weeks old plant and soil samples were collected from each pot to measure available $P$ by Olsen method. Both $L$ and $P$ and their combinations had significant $(P<$ 0.001 ) effects on shoot and root biomass, shoot and root $P$ concentrations, $P$ uptake by Indian spinach and $P$ availability. Although lime and $P$ increased biomass production, $P$ concentrations of shoot and root, and its uptake by Indian spinach and available $P$, this effect was boosted by combining $L$ with $P$ applied. $1000 \mathrm{~kg}$ lime plus $100 \mathrm{~kg} P$ were adequate for plant growth. Available $P$ was strongly and positively correlated $\left(R^{2}=0.909, P=\right.$ 0.000) with $P$ uptake by plant. Results of the present study indicated that lime and phosphorus could be used in combination to enhance plant growth.

\section{KEYWORDS}

Lime; Phosphorus; Acid Soil; Soil Available P; Yield; Indian Spinach

\section{Introduction}

Phosphorus limits the crop production because only about $20 \%$ of applied phosphorus is utilized by crop and remaining part is converted into insoluble forms [1]. Soluble phosphorus, either from fertilizer or natural weathering, reacts with clay, iron, and aluminum compounds in the soil and is converted readily to less available forms by the process of phosphorus fixation. Because of these fixation processes, phosphorus moves very little in most soils (less than an inch in most soils). Phosphorus deficiencies and aluminum toxicities often occur simultaneously in many acid soils and are thought to be responsible for poor crop yields in such soils [2]. Fertilization with $\mathrm{P}$ in the absence of lime resulted in lower yield than

${ }^{*}$ Corresponding author. where lime was applied. In highly weathered, acid soils around the world, $\mathrm{P}, \mathrm{Ca}$, and $\mathrm{Mg}$ deficiencies and $\mathrm{Al}$ and Mn toxicities are the most important nutritional and/or element disorders that limit the crop yields [3-5].

Liming enhances available $\mathrm{P}$ in soil [6]. An increasing response to applied $\mathrm{P}$ with increasing rates of added lime have been attributed to either an improved rate of supply of P by the soil or an improved ability of the plant to absorb P when Al toxicity has been eliminated [7]. Several laboratory and field studies have been undertaken to determine how phosphorus availability responds to lime addition. Information on the effect of liming on $\mathrm{P}$ sorption is not consistent. Some studies suggested that liming decreases the P sorption by soils [8], while other reported increased P sorption due to liming [9] and some observed effect of liming on P sorption was nil [10]. Therefore, 
studies are needed to understand the interaction of lime and phosphorus on the availability of $\mathrm{P}$ to plants.

Indian spinach (Basella alba L.) one of the important and popular vegetable crops in Bangladesh was used as a test plant in this study. The main objective of this study was to investigate the effect of lime and phosphorus on yield, availability of phosphorus and their uptake by Indian spinach.

\section{Materials and Methods}

\subsection{Experimental Site and Design}

A pot experiment was carried out in the crop field of the Department of Soil Science, University of Chittagong, Bangladesh, using a sandy loam surface soil $(0-15 \mathrm{~cm})$.

The treatments were lime (L) at 0, 500, 1000 and 2000 $\mathrm{kg} \mathrm{CaCO}_{3} \mathrm{ha}^{-1}$ and phosphorus (P) at 0, 50, 100 and 150 $\mathrm{kg} \cdot \mathrm{P} \cdot \mathrm{ha}^{-1}$ as triple supper phosphate (TSP) in a $4 \times 4$ factorial combination in a CRD replicated thrice. The earthen pots were filled with $5.0 \mathrm{~kg}$ air-dried soils after sieved through $4 \mathrm{~mm}$ mesh and mixing $\mathrm{L}$ and $\mathrm{P}$. Five seeds of Indian spinach were sown to each pot and water was applied up to the field capacity. After emergence, 3 healthy seedlings were kept in each pot. The plants were harvested after 10 weeks of growth. Prior to harvesting, soil samples from each pot were taken for chemical analysis. After harvest, the plants were separated into shoots and roots. The shoots and roots were air dried for several days and oven dried at $65^{\circ} \mathrm{C}$ for 72 hours and dry biomass were recorded. Soil samples were collected from each pot after harvest to measure soil available P.

\subsection{Laboratory and Data Analysis}

Air dried soils sieved through $2 \mathrm{~mm}$ mesh were analyzed for $\mathrm{pH}$ (Soil: $\left.\mathrm{H}_{2} \mathrm{O} ; 1: 2.5\right)$ of 5.16, CEC of $4.18\left(\mathrm{cmol} \cdot \mathrm{kg}^{-1}\right)$ (extraction with $1 \mathrm{M} \mathrm{NH}_{4} \mathrm{OAc}$ ) [11], texture [12] and organic carbon of $0.98 \%$ [13]. Plant samples were ground and passed through $2 \mathrm{~mm}$ sieve for analysis. Total $\mathrm{P}$ in soil $(0.05 \%)$ and plant tissues were determined colorimetrically by ascorbic acid blue color method [14] after digestion with $\mathrm{H}_{2} \mathrm{O}_{2}-\mathrm{H}_{2} \mathrm{SO}_{4}$ [15] and the absorbance was measured by spectrophotometer at wave length of $882 \mathrm{~nm}$. Olsen available $\mathrm{P}\left(3.25 \mathrm{mg} \cdot \mathrm{kg}^{-1}\right)$ was determined by Olsen method [16].

Microsoft Excel and MINITAB program [17] were used for analysis of variance and correlation. Significant means were separated using Tukey's Multiple Range Test (TMRT). The nutrient uptake of the plants was calculated by multiplying the nutrient concentration in the tissue and the dry matter (DM) yield.

\section{Result}

\subsection{Effect of Lime and Phosphorus on Dry Matter Yield}

Variations in shoot and root biomass due to liming were statistically significant $(P<0.001)$ which ranged from 5.29 to $17.12 \mathrm{~g} \cdot \operatorname{pot}^{-1}$ and 1.35 to $3.27 \mathrm{~g} \cdot \operatorname{pot}^{-1}$ respectively (Table 1). Maximum shoot biomass was obtained from $2000 \mathrm{~kg}$ lime followed by $1000 \mathrm{~kg}$ lime. Untreated control plants (without lime) gave the lowest shoot biomass and it was statistically identical with $500 \mathrm{~kg}$ lime. Application of $1000 \mathrm{~kg}$ lime increased root biomass progressively giving maximum (3.27 g.pot ${ }^{-1}$ ) followed by 2000 $\mathrm{kg}$ lime. Plants grown without lime gave the lowest root biomass.

Significant variations $(P<0.001)$ in shoot and root biomass were also observed due to $\mathrm{P}$ fertilizer (Table 2). Application of $150 \mathrm{~kg} P$ increased both shoot and root biomass progressively giving maximum and it was statis-

Table 1. Effect of lime and phosphorus on dry matter yield of Indian spinach.

\begin{tabular}{|c|c|c|c|c|c|c|}
\hline \multirow{2}{*}{ Item } & \multirow{2}{*}{ 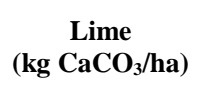 } & \multicolumn{5}{|c|}{ Phosphorus (kg·P/ha) } \\
\hline & & 0 & 50 & 100 & 150 & Mean \\
\hline \multirow{5}{*}{$\begin{array}{l}\text { Shoot biomass } \\
\quad\left(g \cdot p^{-1}\right)\end{array}$} & 0 & $0.51 \pm 0.03$ & $3.21 \pm 0.30$ & $7.43 \pm 0.48$ & $10.03 \pm 0.21$ & $5.29 \mathrm{c}$ \\
\hline & 500 & $0.95 \pm 0.05$ & $4.96 \pm 0.24$ & $10.37 \pm 0.47$ & $10.95 \pm 0.37$ & $6.81 c$ \\
\hline & 1000 & $3.81 \pm 0.28$ & $11.72 \pm 0.64$ & $18.48 \pm 0.40$ & $20.48 \pm 0.43$ & $13.62 \mathrm{~b}$ \\
\hline & 2000 & $5.09 \pm 0.12$ & $14.41 \pm 0.28$ & $22.50 \pm 1.22$ & $26.34 \pm 0.48$ & $17.12 \mathrm{a}$ \\
\hline & Mean & $2.59 \mathrm{c}$ & $8.61 \mathrm{~b}$ & $14.69 \mathrm{a}$ & 16.95 a & \\
\hline \multirow{4}{*}{$\begin{array}{l}\text { Root biomass } \\
\quad\left(\mathrm{g} \cdot \mathrm{pot}^{-1}\right)\end{array}$} & 0 & $0.16 \pm 0.01$ & $0.92 \pm 0.06$ & $1.84 \pm 0.06$ & $2.48 \pm 0.10$ & $1.35 \mathrm{~d}$ \\
\hline & 500 & $0.23 \pm 0.01$ & $4.13 \pm 0.09$ & $2.62 \pm 0.00$ & $2.98 \pm 0.03$ & $1.83 \mathrm{c}$ \\
\hline & 1000 & $1.10 \pm 0.04$ & $3.67 \pm 0.18$ & $4.13 \pm 0.09$ & $4.17 \pm 0.05$ & $3.27 \mathrm{a}$ \\
\hline & 2000 & $0.52 \pm 0.04$ & $2.43 \pm 0.35$ & $3.96 \pm 0.18$ & $4.40 \pm 0.06$ & $2.83 \mathrm{~b}$ \\
\hline
\end{tabular}

Values followed by different letters in the column or row of mean are significantly different from each other at $P<0.05$; “ \pm ” denotes standard deviation. 
Table 2. Effect of lime and phosphorus on $P$ concentrations, $P$ uptake and $P$ availability.

\begin{tabular}{|c|c|c|c|c|c|c|}
\hline \multirow{2}{*}{ Item } & \multirow{2}{*}{$\begin{array}{c}\text { Lime } \\
(\mathrm{kg} \mathrm{CaCO} \\
3\end{array}$} & \multicolumn{5}{|c|}{ Phosphorus (kg·P/ha) } \\
\hline & & 0 & 50 & 100 & 150 & Mean \\
\hline \multirow{5}{*}{$\begin{array}{c}\text { Shoot P } \\
(\%)\end{array}$} & 0 & $0.11 \pm 0.01$ & $0.14 \pm 0.01$ & $0.25 \pm 0.01$ & $0.33 \pm 0.01$ & $0.21 \mathrm{~d}$ \\
\hline & 500 & $0.13 \pm 0.01$ & $0.34 \pm 0.06$ & $0.55 \pm 0.01$ & $0.58 \pm 0.01$ & $0.40 \mathrm{c}$ \\
\hline & 1000 & $0.34 \pm 0.01$ & $0.59 \pm 0.01$ & $0.69 \pm 0.01$ & $0.70 \pm 0.01$ & $0.58 \mathrm{a}$ \\
\hline & 2000 & $0.21 \pm 0.02$ & $0.41 \pm 0.00$ & $0.65 \pm 0.01$ & $0.69 \pm 0.01$ & $0.49 \mathrm{~b}$ \\
\hline & Mean & $0.20 \mathrm{c}$ & $0.37 \mathrm{~b}$ & $0.54 \mathrm{a}$ & $0.58 \mathrm{a}$ & \\
\hline \multirow{5}{*}{$\begin{array}{c}\text { Root P } \\
(\%)\end{array}$} & 0 & $0.14 \pm 0.01$ & $0.23 \pm 0.03$ & $0.34 \pm 0.04$ & $0.42 \pm 0.01$ & $0.28 \mathrm{c}$ \\
\hline & 500 & $0.18 \pm 0.02$ & $0.30 \pm 0.02$ & $0.44 \pm 0.02$ & $0.48 \pm 0.01$ & $0.35 \mathrm{~b}$ \\
\hline & 1000 & $0.22 \pm 0.02$ & $0.31 \pm 0.01$ & $0.57 \pm 0.05$ & $0.66 \pm 0.06$ & $0.46 \mathrm{a}$ \\
\hline & 2000 & $0.19 \pm 0.03$ & $0.31 \pm 0.01$ & $0.45 \pm 0.02$ & $0.52 \pm 0.01$ & $0.38 \mathrm{~b}$ \\
\hline & Mean & $0.18 \mathrm{~d}$ & $0.31 \mathrm{c}$ & $0.45 \mathrm{~b}$ & 0.52 a & \\
\hline \multirow{5}{*}{$\begin{array}{c}\text { Plant P } \\
\text { uptake } \\
\left(\mathbf{m g}^{\prime} \cdot \text { pot }^{-1}\right)\end{array}$} & 0 & $0.77 \pm 0.05$ & $6.59 \pm 0.56$ & $24.83 \pm 1.17$ & $43.51 \pm 1.33$ & $17.50 \mathrm{~b}$ \\
\hline & 500 & $1.65 \pm 0.13$ & $21.19 \pm 3.74$ & $68.99 \pm 3.13$ & $77.93 \pm 1.12$ & $33.42 \mathrm{~b}$ \\
\hline & 1000 & $15.49 \pm 1.23$ & $83.0 \pm 5.53$ & $151.17 \pm 6.15$ & $171.66 \pm 5.50$ & $64.30 \mathrm{a}$ \\
\hline & 2000 & $11.48 \pm 0.99$ & $66.59 \pm 0.41$ & $164.11 \pm 7.25$ & $203.77 \pm 2.34$ & $79.80 \mathrm{a}$ \\
\hline & Mean & $7.35 \mathrm{c}$ & $44.29 \mathrm{~b}$ & $102.30 \mathrm{a}$ & $124.20 \mathrm{a}$ & \\
\hline \multirow{5}{*}{$\begin{array}{c}\text { Available P } \\
\left(\mathrm{mg}^{2} \mathbf{k g}^{-1}\right)\end{array}$} & 0 & $3.23 \pm 0.01$ & $5.46 \pm 0.05$ & $8.44 \pm 0.79$ & $15.48 \pm 0.61$ & $8.15 \mathrm{~b}$ \\
\hline & 500 & $3.68 \pm 0.01$ & $8.59 \pm 0.62$ & $9.76 \pm 0.53$ & $18.01 \pm 0.59$ & $10.01 \mathrm{~b}$ \\
\hline & 1000 & $4.05 \pm 0.35$ & $9.63 \pm 0.51$ & $22.46 \pm 2.04$ & $30.33 \pm 1.52$ & $16.62 \mathrm{a}$ \\
\hline & 2000 & $4.53 \pm 0.11$ & $11.06 \pm 1.32$ & $24.58 \pm 0.73$ & $32.53 \pm 0.81$ & $18.11 \mathrm{a}$ \\
\hline & Mean & $3.88 \mathrm{~d}$ & 8.62 c & $16.31 \mathrm{~b}$ & 24.09 a & \\
\hline
\end{tabular}

Values followed by different letters in the column or row of mean are significantly different from each other at $P<0.05$; “ \pm ” denotes standard deviation.

tically identical with $100 \mathrm{~kg}$ P. The lowest shoot and root biomass production were obtained from $0 \mathrm{~kg} P$.

Interaction of lime and phosphorus levels also showed significant influence on shoot and root biomass (Table 1). Shoot and root biomass varied from 0.51 to $26.34 \mathrm{~g} \cdot \mathrm{pot}^{-1}$ and 0.16 to $4.40 \mathrm{~g} \cdot \mathrm{pot}^{-1}$ respectively due to different levels of lime and $\mathrm{P}$ (Table 1). Although lime and $\mathrm{P}$ increased biomass production, this effect was boosted by combining lime with $\mathrm{P}$ applied. For instance, biomass (both shoot and root) produced by combining $1000 \mathrm{~kg}$ lime with $100 \mathrm{~kg} \mathrm{P}$ is double the biomass obtained from $100 \mathrm{~kg} \mathrm{P}$ applied alone. The highest biomass was obtained by combining $2000 \mathrm{~kg}$ lime with $150 \mathrm{~kg}$ P.

\subsection{Effects of Lime and Phosphorus on Shoot and Root P, Plant P Uptake and Soil Available $\mathbf{P}$ after Harvest}

Both lime and $\mathrm{P}$ and their interaction had significant effects $(\mathrm{P}<0.001)$ on shoot and root $\mathrm{P}$, plant $\mathrm{P}$ uptake and soil $\mathrm{P}$ availability (Table 2). Maximum shoot and root $\mathrm{P}$ were obtained from $1000 \mathrm{~kg}$ lime followed by $2000 \mathrm{~kg}$ lime. Application of $2000 \mathrm{~kg}$ lime increased both plant P uptake and soil available $\mathrm{P}$ and it was statistically identical with $1000 \mathrm{~kg}$ lime. Plants grown without lime gave the lowest value for shoot $\mathrm{P}$, root $\mathrm{P}$, plant $\mathrm{P}$ uptake and soil available $P$.

Application of $150 \mathrm{~kg}$ P increased shoot P, root P, plant $\mathrm{P}$ uptake and soil $\mathrm{P}$ availability progressively giving maximum and it was statistically identical with 100 $\mathrm{kg} \mathrm{P}$ for shoot $\mathrm{P}$ and plant $\mathrm{P}$ uptake (Table 2).

Shoot and root P varied from 0.11 to $0.70 \%$ and 0.14 to $0.66 \%$ respectively due to different levels of lime and $\mathrm{P}$ (Table 2). Plant $\mathrm{P}$ (both shoot and root) obtained by combining $1000 \mathrm{~kg}$ lime with $100 \mathrm{~kg} P$ about double the plant P obtained from $100 \mathrm{~kg} P$ applied alone. The highest shoot $\mathrm{P}$ was obtained by combining $1000 \mathrm{~kg}$ lime with $150 \mathrm{~kg}$ P but no significant difference was observed between this and results recorded from $1000 \mathrm{~kg}$ lime plus $100 \mathrm{~kg} \mathrm{P}$ and $2000 \mathrm{~kg}$ lime plus 100 or $150 \mathrm{~kg}$ P. Uptake of P obtained by combining $1000 \mathrm{~kg}$ lime with $100 \mathrm{~kg}$ P about six times the plant $\mathrm{P}$ uptake obtained from $100 \mathrm{~kg}$ $\mathrm{P}$ applied alone. Liming without $\mathrm{P}$ increased soil available $\mathrm{P}$, though not to critical levels (Olsen available $\mathrm{P}<$ $10 \mathrm{mg} \cdot \mathrm{kg}^{-1}$ ) required for plant growth (Table 2). Lime addition of $1000 \mathrm{~kg}$ with $100 \mathrm{~kg}$ P resulted into P avail- 
ability above critical level (22.46 $\left.\mathrm{mg} \cdot \mathrm{kg}^{-1}\right)$ required for plant growth. At the same rates, $\mathrm{P}$ without lime tended to result into relatively lower $\mathrm{P}$ availability. Shoot and root p, uptake of $P$ increased with $P$ availability.

The available $\mathrm{P}$ was significantly and positively correlated $\left(\mathrm{R}^{2}=0.909, P=0.000\right)$ with $\mathrm{P}$ uptake by plant which indicated suitability of Olsen $\mathrm{P}$ to predict plant available P (Figure 1).

\section{Discussion}

In general, biomass of shoot and root was higher with the combined application of lime and P than P or lime alone. The present findings are in accordance with the findings that lime with P inputs significantly increased the dry matter yield compared to the control but when lime was applied without $\mathrm{P}$, biomass did not increase significantly above the control [18]. This indicated that $\mathrm{P}$ was a limiting factor in this soil. Trends in biomass and total P uptake roughly followed one another generally increasing with both increased $\mathrm{P}$ and lime additions. Lime additions may have improved the growth media and hence increased biomass and $\mathrm{P}$ uptake due to liming may be due to the fact that it breaks the $\mathrm{Al}$ and $\mathrm{Fe}$ phosphates in soil, thereby making $\mathrm{P}$ available to plant. Besides, available $\mathrm{P}$ status increase may be due to increase in mineralization of organic $P$ as affected by lime [19].

Increase in Olsen $\mathrm{P}$ was observed when $\mathrm{P}$ was applied in combination with lime because liming reduces the activity of $\mathrm{Fe}$ and $\mathrm{Al}$ hydroxide and brings phosphorus $\left(\mathrm{H}_{2} \mathrm{PO}_{4}^{-}\right)$to calcium monophosphate form [20]. Both phosphorus and lime increased $\mathrm{P}$ availability which was reflected in increased shoot P [21]. Available P increased with increased phosphate application which in turn increased dry matter yield and uptake of phosphorus by plant [22]. TSP, when applied alone, gave the high amounts of available $\mathrm{P}$, but it did not give the highest $\mathrm{P}$ uptakes implying that some other factor, possibly $\mathrm{Al}$ toxicity, was preventing proper utilization of $\mathrm{P}$ by plants. A reduction in exchangeable $\mathrm{Al}$ by application of lime led to increased nutrient uptake [18].

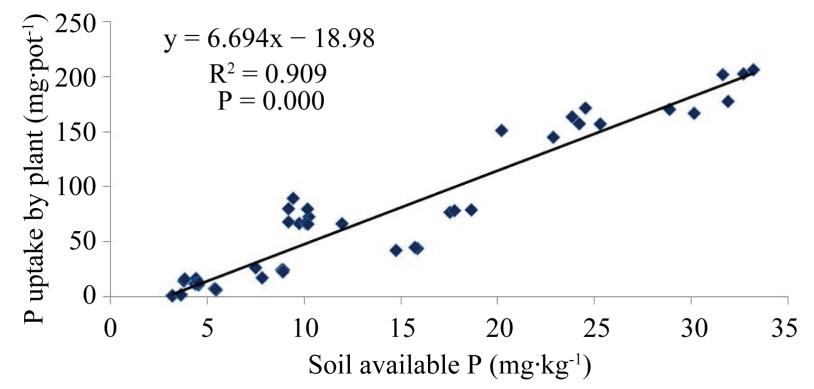

Figure 1. Correlations of available $P$ with $P$ uptake by Indian spinach.

\section{Conclusion}

From the results of the present study, it could be concluded that yield, plant $\mathrm{P}$ concentration, $\mathrm{P}$ uptake and available $\mathrm{P}$ increased with increasing rates of $\mathrm{P}$ and lime additions to soil. Additions of lime of $1000 \mathrm{~kg}$ plus 100 $\mathrm{kg} \mathrm{P}$ were adequate for plant growth. The magnitude of increase was higher when $\mathrm{P}$ was applied in soil in combination with lime. So it could be used in combination with $\mathrm{P}$ fertilizer in the case of $\mathrm{P}$ deficient acidic soil.

\section{REFERENCES}

[1] Y. P. Dubey, B. P. Kaistha and R. C. Jaggi, "Influence of Irrigation and Phosphorus on Growth, Green Pod Yield and Nutrient Uptake of Pea (Pisum sativum) in Lahaul Valley of Hiamachal Pradesh," Indian Journal of Agronomy, Vol. 44, 1999, pp. 137-140.

[2] P. A. Sanchez and J. G. Salinas, "Low Input Technology for Managing Oxisols and Ultisols in Tropical America," Advances in Agronomy, Vol. 34, 1981, pp. 279-406. http://dx.doi.org/10.1016/S0065-2113(08)60889-5

[3] D. R. Parker, T. B. Kinraide and L. W. Zelazny, "On the Phytotoxicity of Polynuclear Hhydroxyaluminum Complexes,” Soil Science Society of America Journal, Vol. 53, 1989, pp. 789-796.

[4] C. D. Foy, "Soil Chemical Factors Limiting Plant Root Growth,” Advances in Soil Science, Vol., 19, 1992, pp. 97-149. http://dx.doi.org/10.1007/978-1-4612-2894-3 5

[5] N. K. Fageria, "Soil Acidity Affects Availability of Nitrogen, Phosphorus and Potassium,” Better Crops International, Vol. 10, 1994, pp. 8-9.

[6] H. Ukrainetz, "Long Term Effects of Liming an Acid Scott Loam on Yield and Phosphorus Nutrition of Wheat and Barley," Proceedings of the Soils and Crops Workshop, University of Saskatchewan, Saskatoon, 1984, pp. 254-265.

[7] D. K. Friesen, A. S. R. Juo and M. H. Miller, "Liming and LimePhosphorus-Zinc Interactions in Two Nigerian Ultisols. I. Interactions in the Soil," Soil Science Society of America Journal, Vol. 44, No. 6, 1980, pp. 1221-1226. http://dx.doi.org/10.2136/sssaj1980.03615995004400060 $\underline{018 \mathrm{x}}$

[8] J. R. Woodruff and E. J. Kamprath, "Phosphorus Adsorption Maximum as Measured by Langmuir Isotherm and Its Relationship to Phosphorus Availability,” Soil Science Society of American Proceedings, Vol. 29, No. 2, 1965, pp. 148-150. http://dx.doi.org/10.2136/sssaj1965.03615995002900020 $\underline{012 x}$

[9] S. L. Amarasiri and S. R. Olsen, "Liming as Related to Solubility of P and Plant Growth in an Acid Tropical Soil," Soil Science Society of American Proceedings, Vol. 37, No. 5, 1973, pp. 716-721.

http://dx.doi.org/10.2136/sssaj1973.03615995003700050 $\underline{026 x}$

[10] N. G. Reeve and M. E. Sumner, "Effects of Aluminium 
Toxicity and Phosphorus Fixation on Crop Growth on Oxisols in Natal," Proceedings of Soil Science Society of America, Vol. 34, No. 2, 1970, pp. 263-269. http://dx.doi.org/10.2136/sssaj1970.03615995003400020 $\underline{025 x}$

[11] Soil Survey Laboratory Staff, "Soil Survey Laboratory Methods Manual," Soils Surv. Invest. Resps, 42, USDASCS, Washington DC, 1992.

[12] G. J. Bouyoucos, "Hydrometer Method Improved for Making Particle Size Analysis of Soils,” Agronomy Journal, Vol. 54, No. 5, 1962, pp. 464-465. http://dx.doi.org/10.2134/agronj1962.0002196200540005 $\underline{0028 \mathrm{x}}$

[13] A. Walkley and I. A. Black, "An Examination of Degtjareff Method for Determining Soil Organic Matter and a Proposed Modification of the Chromic Acid Titration Method," Soil Science, Vol. 37, No. 1, 1934, pp. 29-38. http://dx.doi.org/10.1097/00010694-193401000-00003

[14] J. Murphy and J. P. Riley, “A Modified Single Solution Methods for the Determination of Available Phosphate in Natural Water," Analytica Chimica Acta, Vol. 27, 1962, pp. 31-36. http://dx.doi.org/10.1016/S0003-2670(00)88444-5

[15] O. O. Akinremi, N. Amisen, M. A. Kashem and H. H. Janzen, "Evaluation of Analytical Methods for Total P in Organic Amendments," Communications in Soil Science and Plant Analysis, Vol. 34, No. 19-20, 2003, pp. 29812991. http://dx.doi.org/10.1081/CSS-120025220

[16] S. R. Olsen, C. V. Cole, F. S. Watanabe and Dean, "Estimation of Available Phosphorus in Soils by Extraction with Sodium Bicarbonate,” USDA Circular No. 939, US Government Printing Office, Washington DC, 1954.

[17] Minitab. Inc., “Minitab User Guide Release 11,” Minitab, State College, 1996.

[18] P. A. Opala, "Comparative Effects of Lime and Organic Materials on Selected Soil Chemical Properties and $\mathrm{Nu}-$ trient Uptake by Maize in an Acid Soil," Archives of Applied Science Research, Scholars Research Library, Vol. 3, No. 1, 2011, pp. 96-107. http://scholarsresearchlibrary.com/archive.html

[19] R. J. Haynes, "Effects of Liming on Phosphate Availability in Acid Soils," Plant and Soil, Vol. 68, No. 3, 1992, pp. 289-308. http://dx.doi.org/10.1007/BF02197935

[20] S. P. Dixit and P. K. Sharma, "Effects of Phosphorus and Lime on Productivity, Phosphorus Uptake by Onion in a Typic Haplustalf of Himachal Pradesh," Indian Journal of Agricultural Sciences, Vol. 74, No. 8, 2003, pp. 479-481.

[21] P. O. Kisinyo, C. O. Othieno, J. R. Okalebo, M. J. Kipsat, A. K. Serem and D. O. Obiero, "Effects of Lime and Phoshorus Application on Early Growth of Leucaena in Acid Soils,” African Crop Science Conference Proceedings, Vol. 7, 2005, pp. 1233-1236.

[22] Pathiram and R. N. Prasad, "Growth of Maize and Phosphorous Uptake Adsorption Characteristics of Acid Soils," Journal of Indian Society of Soil Science, Vol. 39, 1991, pp. 302-307. 